

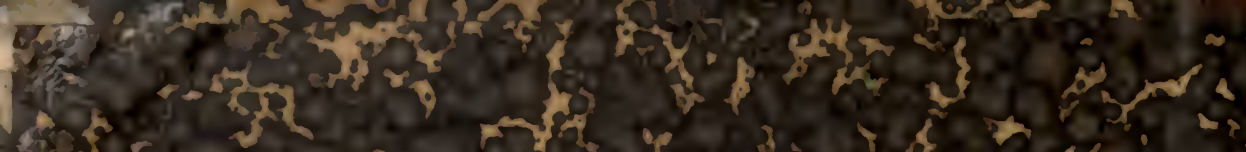

(3)

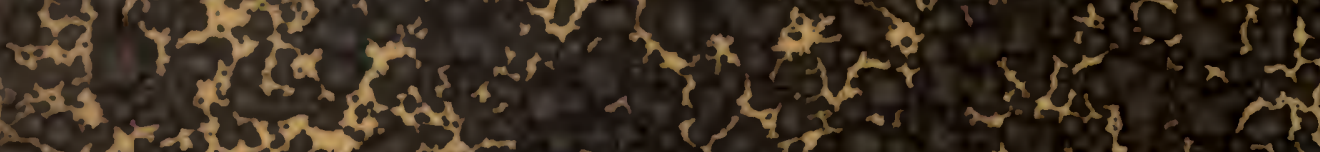

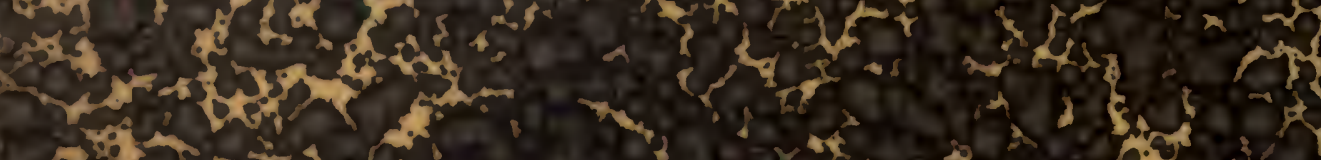

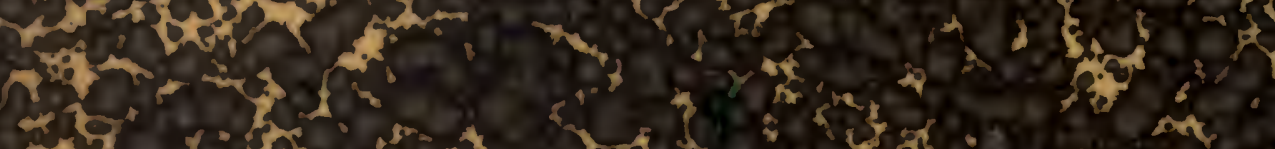

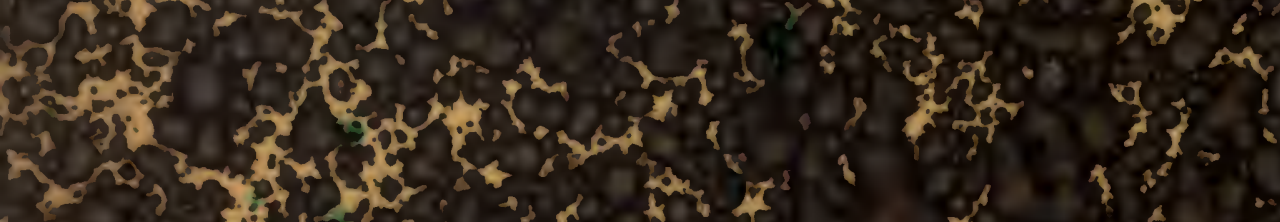

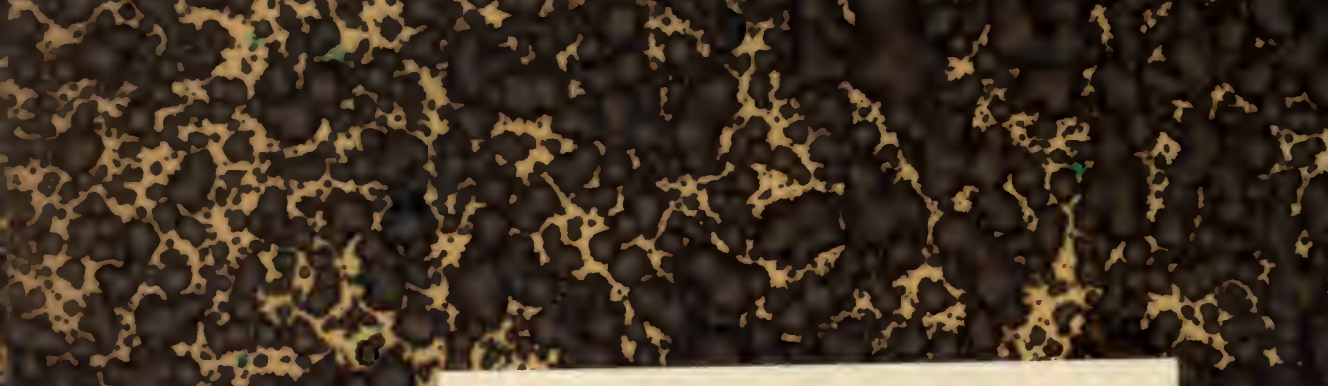

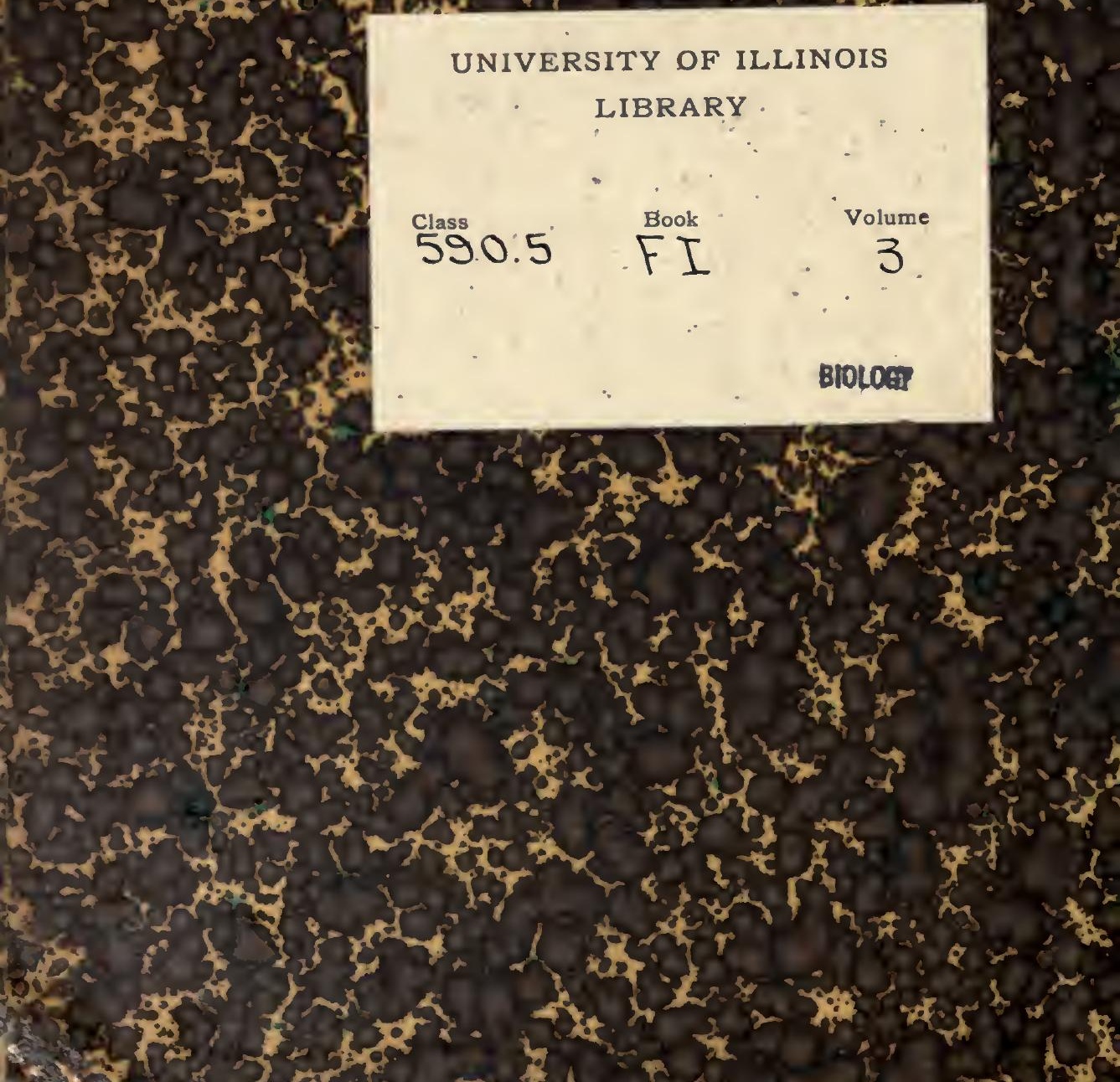




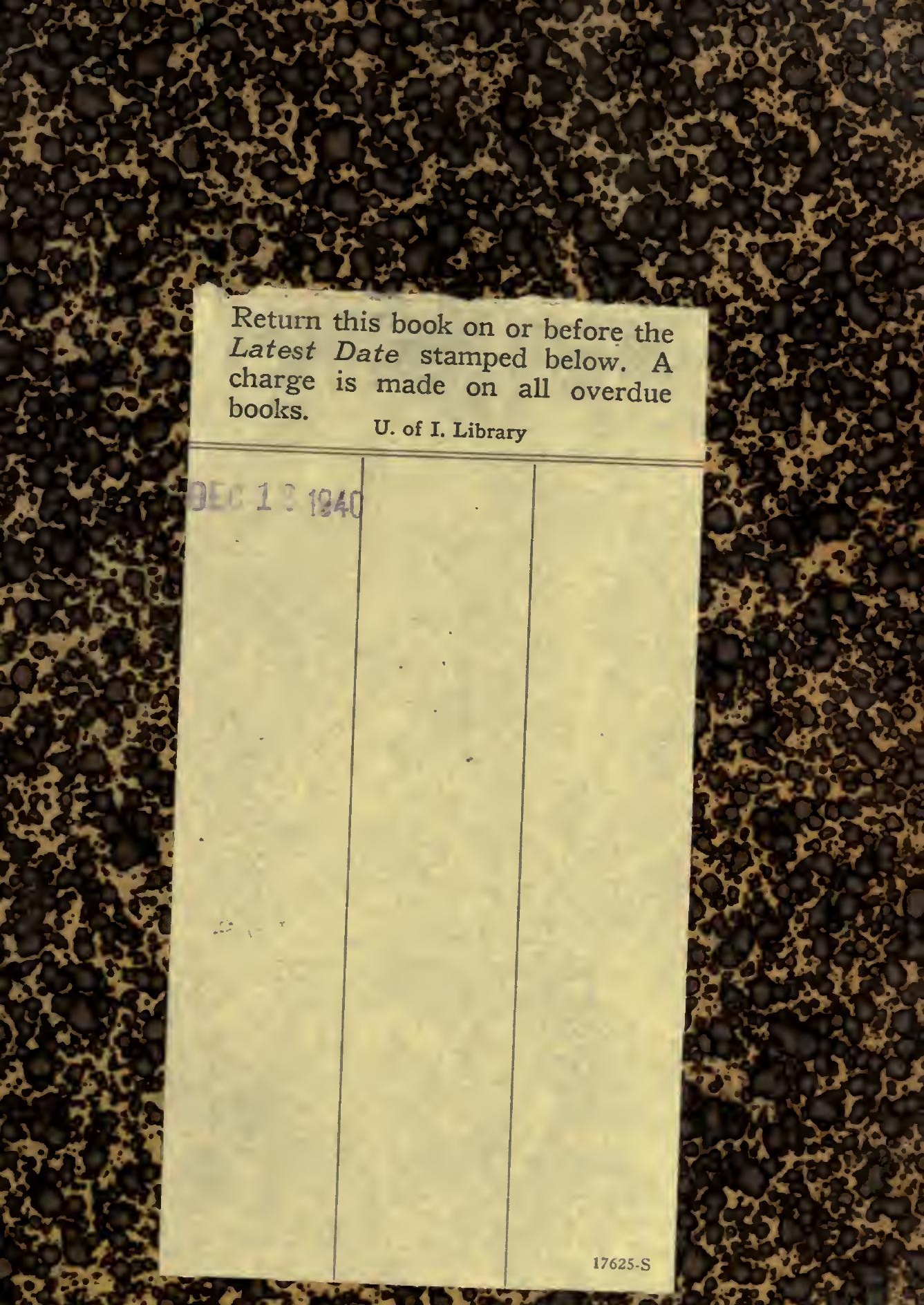

Wh

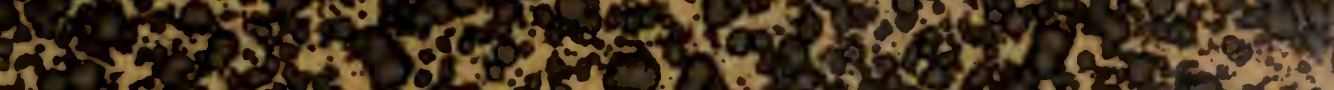

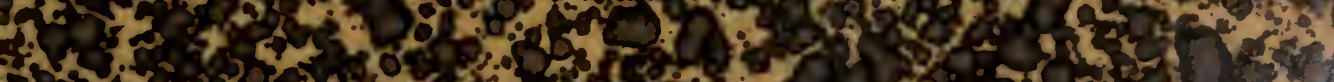

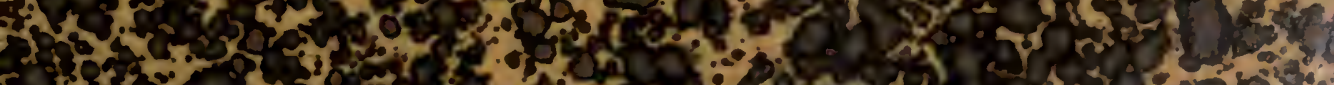

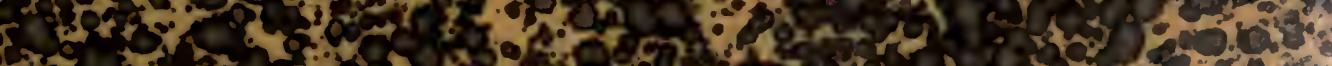

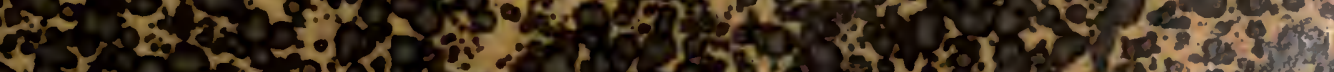

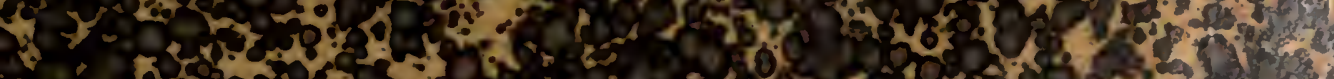

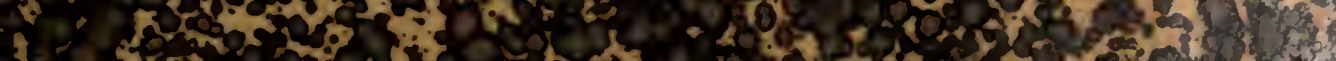
(1. 

Fieldiana 

goobiguat serues V.3 



\section{Field Columbian Museum}

Publication 76

Zoölogical Series

Vol. III, No. II

A LIST OF MAMMALS

OBTAINED BY

EDMUND HELLER

COLLECTOR FOR THE MUSEUM

FROM THE

\section{COAST REGION OF NORTHERN CALIFORNIA AND OREGON}

D. G. Elliot, F. R. S. E., Etc.

Curator of Department.

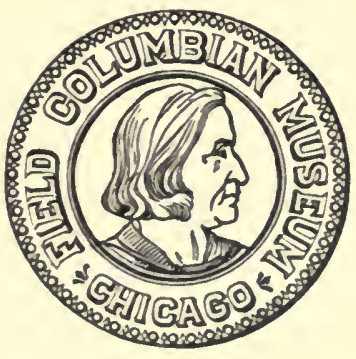

Chicago, U. S. A.

Nay, 1903 



\title{
A LIST
}

\section{OF MAMMALS OBTAINED BY EDMUND HELLER, COLLECTOR FOR THE MUSEUM, FROM THE COAST REGION OF NORTHERN CALIFORNIA AND OREGON.}

\author{
BY D. G. ELLIOT, F.R.S.E., ETC.
}

In the spring of $1901, \mathrm{Mr}$. Edmund Heller started from San Francisco on a trip along the coasts of California and Oregon to obtain specimens of mammals for this institution, visiting as many of the type localities as possible on his route. His first collecting place was Nicasio, Marin County, type locality of Microtus californicus, not far from San Francisco. This locality Mr. Heller describes as follows: "Nicasio is situated in a small valley surrounded by rather high rolling. hills, the highest of about one thousand feet. The northern slopes of the hills are heavily forested by Sequoia sempervirens, Pseudotsuga taxifolia, Inersus densiftora, Umbellulario californica, and other Transition trees. The southern slopes are open and covered by a good growth of grass which is used for pasturage. The valleys are also chiefly grass lands with a few scattered Quercus agrifolia and $Q$. lobata. Two life zones are present. The Transition is limited to the northern slopes of the hills and cold cañons, and is marked by the range of Sequoia and Pseudotsuga timber. Haplodontia and Tamias are here characteristic of this zone. The upper Sonoran zone is limited to the valleys and southern hillsides, and covers much the greater part of the country." Mr. Heller remained at Nicasio for two weeks, and then went to Point Reyes, on the coast, type locality of Haplodontia phrea and Putorius x. mundus, and passed a week there. Of this place he says: "The Point Reyes peninsula is well separated east of the line of the North Pacific Railroad by a low divide which extends from the southern end of Tomales Bay to Bolinas, and is formed of high hills of over a thousand feet, heavily forested by Pinus muricata, Pseudotsuga taxifolia, Umbellulario californica, Inersus densiflora, Arbutus mensisi, etc. That part of the peninsula west and north of Drake's Bay is a low and sandy plain with a frontage of sand-dunes along the coast. The peninsula was at one time evidently an island, the low divide having been gradually filled in by the creeks flowing into Tomales and Bolinas bays. The whole peninsula is in the Transition 
zone, the climate very cold for the latitude, due to the heavy winds and fogs constantly occurring." 'The next collecting place was Petaluma, a short distance north of Point Reyes, and the type locality of Rinithrodontomys longicauda and Neotoma fuscipes, where but a brief stay was made, and then Mr. Heller proceeded to Mendocino, the type locality of Tamias t. ochrogenys and Peromyscus o. mubidus, where he remained ten days and procured a number of desirable specimens. Mendocino he states "is on the sea coast at the mouth of Big River, a stream about seventy-five yards wide where it enters the sea, and is subject to the influence of the tide four miles above its mouth. 'The town is on a low plateau that slopes gradually to the ocean, the coast slope being chiefly open and grassy, except where cut into small cañons by streams which are heavily forested on their banks. Four or five miles back from the coast the hills grow higher, forming mountains of several thousand feet elevation. The plateau, cañons, and mountains are heavily forested with Sequoia, Pseudotsuga, Abies, etc. Near the coast Pinus muricata is the most abundant tree, but it does not extend inlanid very far. The whole region is Transition except perhaps the higher mountains, where the Canadian may be found." Of the mammals of this locality not procured may be mentioned Spermophilus \%. beecheyi, which was said to be "common a few miles inland in grain fields, and also to the southward about Point Arena." It was said to have only appeared in the region since the establishment of grain fields. Another species, the sea otter, Latax lutris, formerly occurred in the Bay of Mendocino, but has not appeared in late years. A trapper reported having seen six about ten years ago.

Ten days were passed in this locality, and then Mr. Heller went to Eureka, type locality of Thomomys laticeps, at which place and its vicinity he remained three weeks; and one week was passed at Scotia in the redwood belt on Eel River south of Eureka. At Table Bluff at the southern end of Table Bay small mammals were abundant, and a considerable number representing various species was taken. Of this country Mr. Heller says, that "except about the mouths of rivers and at Humboldt Bay, it consists of high hills and mountains covered by heavy forests of Sequoia, Pseudotsuga, Abies, Picea, etc. About Humboldt Bay the land is low and rolling, and the uncultivated portions are covered by a thick growth of ferns (Pteris) and shrubs, chiefly Pubus and Gaultheria. Most of the region appears to be in the lower part of the Canadian zone, especially that portion bordering the coast where Picea sitkensis is found. Indeed, for ten or twelve miles where the heavy fogs do not penetrate it is much warmer and the vegetation is chiefly Transition in character." 
Requa was the next place visited, considerably to the north of Eureka, and situated on the Klamath River, which at its mouth Mr. Heller states is "bordered by rather steep hills with occasional small fats interspersed among them. Most of these hills are heavily forested with Picea, Pseudotsuga and Sequoia. A few bald hills occur which lack trees and support only a growth of ferns and bushes, but these are found usually a considerable distance up the river. The dominant tree about the mouth of the Klamath is Picea sitkensis, which grows to an immense size on the rich bottom lands. The giant arborvitæ Thuy accidentalis finds its southern limit here and Tsuga heterophylla is also quite abundant. All three of these trees are characteristic of the Canadian zone in which the whole coast line is situated. Fifteen or twenty miles inland the Transition zone occurs in which oaks and Douglas fir predominate, and Picea and Sequoia are lacking." Sea lions are common off the coast and also in the Klamath River, which they ascend for several miles to feed upon the salmon; also seals, Phoca richardi, are plentiful and destroy a great many salmon. At Requa was first procured the wood-rat I have called Teonoma $f$. apicalis. From Requa Mr. Heller went to Crescent City, type locality of Microtus angusticeps, near the boundary line of California and Oregon, where he remained eight days. He says of this place that it is "situated in a low level country, which extends from the hills five miles south of the town to the mouth of Smith River a somewhat greater distance to the north. The region contains a considerable number of lakes and is generally swampy where not forested. Spruce and Douglas fir are the commonest trees near the coast, but inland a few miles the redwood forests extend unbroken north and south, and with a width of six to ten miles."

Passing now into Oregon the first stop was at Goldbeach, where a stay of one month was made. Of this place Mr. Heller writes that it is "situated in a hilly region at the mouth of Rogue River." The hills rise abruptly from the river to heights ranging from five hundred to fifteen hundred feet, their summits usually gently rouncled or comparatively level, and composed largely of serpentine rock which supports a fair growth of grass or brush, but few or no trees. The forests are confined mainly to the cañons or hillsides, but are not absent from the ridges where these are composed of soft rocks or soil.

'The furests consist chiefly of the Douglas fir, Pseudotsuga taxifolia. Near the coast Abies amabilis, Picea sitkensis, and Pinus contorta form a fair portion of the timbered areas. Away from the coast Chamacyparis lan'soniana is a fairly common forest tree. The tan-bark oak. California laurel, red alder, big leaf maple, and madroño are common 
trees along streams, and seldom form forests of any extent. The region is apparently in the Canadian zone, but the open grassy nature of the hills and the presence of Citellus $v$. douglasi give it a Transition aspect."

At Goldbeach a new species of Thomomys was procured which has been named after its captor, and also a new form of Peromyscus, and in the district between Crescent City and this first Oregon station, Sciurus douglasi and $S$. $d$. mollipilosus appear to intergrade, individuals that may be attributed to either form having been taken in both places. The only specimen of Sciuropterus secured during the entire journey was taken at Goldbeach, where it was said to be of rare occurrence.

Mr. Heller writes of the animals not collected that a small colony of beaver, Castor c. pacificus, is said to "inhabit a wooded island a few miles up the river. The trappers distinguish two species, a black form which builds houses, and the common reddish brown form which lives in holes along the banks."

From Goldbeach Mr. Heller went to Agness, "a small station at the mouth of the Illinois River about thirty miles from the mouth of the Rogue River,"'where he passed a week in the mountains hunting black bear unsuccessfully. He procured two black-tailed deer, $O$. columbianus, and only a few small mammals of the same species obtained at Goldbeach. Proceeding northward along the coast, Marshfield was the next collecting station, where two weeks were passed. Mr. Heller writes that the "marshes near the town of Marshfield are infested by Mus norvegicus and $M$. musculus, which made trapping rather disagreeable. The Coos Bay is more isolated than any other I have made collections in, and is perhaps better characterized by what it lacks than in any other way. The region has no connection by its streams with the Willamette Valley or the Cascade Range as does most of the country drained by the larger streams, and this perhaps accounts for the absence of such genera as Thomomys, Citellus and Erethizon, etc." At Marshfield the chipmunk that I have characterized as Tamias $t$. littoralis was first met with. Gardiner was the next stopping place, "in a low, hilly region on the Umpqua near its mouth. The region is intermediate in character between the sand-dunes of the coast and the low rolling country flanking the mountains. It is a country of low hills and lakes and deep lagoons along the rivers. The rock formation is chiefly horizontally bedded soft sandstone which has been cut into rather deep ravines by the streams. The deep sloughs and the great inland extension of the tide would suggest a sinking, or rather sunken, coast. The country bordering the sand-dunes is 
thickly covered by Pinus contorta; farther inland it is overgrown with spruce, Picea sitkensis, fir, Pseudotsuga taxifolia, and cedar Thuya gigantea." Here was obtained the wood-rat, Teonoma $f$. apicalis. Proceeding northward, Florence on the Lower Sinslaw River was the next place visited. "The Lower Sinslaw," says Mr. Heller "flows through a sandstone region cut into numerous low, rounded hills. The coniferous forest which clothed the lower hills near the mouth has been removed by fire many years ago. The blackened stumps of this forest are still standing, but the country has been overgrown with alders, Alnus oregonus. A few firs still remain along the streams and in the cañons. The river is subject to tide for about twenty miles from its mouth. Tide-flats, tide-swamps, and lagoons are numerous along the lower part of the river near the mouth, and between the sand-dunes and the hills, lakes are numerous. Near the coast the scrub pine, Pinus contorta, is the commonest tree; farther inland and about the lakes and tide-water the spruce is predominant. Still farther inland and on the higher ground the Douglas fir and red cedar are the prevailing conifers." Haplodontia pacifica was common here on the north fork of the Sinslaw River, and a series of specimens was procured and also the new form of muskrat, I have named $F$. occipitalis on account of the unusual formation of the skull. It is the largest known species of the genus.

Beaverton, type locality of Lepus $f$. ubericolor, was next risited in order to procure the rare and little known Thomomy's bulbivorus, a good series of which was obtained. On account of the peculiar cranial characters of this animal, I have made it the type of a new subgenus. Of Beaverton Mr. Heller writes that it is "near the Columbia River, where the Willamette Valley enters the valley of the Columbia. The region is low and rolling, but hills are entirely lacking in the immediate vicinity of the town. The timbered land is covered with forests of yellow pine, Pinus jeffreyi, Douglas fir, Pseudotsuga taxifolia, white. oaks, Quercus zarryana, etc. A sinall stream which was formerly noted for its beaver-dams flows through the town. The soil is chiefly a heavy black adobe except on the higher parts where it is largely clay. The region is evidently Transition in the character of its vegetation as shown by the presence of the yellow pine and white oak. The beaver which was formerly quite abundant is now nearly or quite extinct." A few may still occur about the head waters of small streams. From Beaverton a short trip was made to McCoy, the type locality of Microtus canicaudus. The place is in "much the same kind of country" as Beaverton, but more level and forested. 'The coast range is about fifteen miles distant. In some places forests of Douglas fir occur, but 
the land is chiefly open and grassy. White oaks and a few yellow pine occur also, and the region I should judge was more 'Iransition than that at Beaverton." The season was now late, December, and the heavy rains had set in, making collecting arduous and difficult, so $\mathrm{Mr}$. Heller was instructed to return south, preparatory to going into Lower California and the San Pedro Martir mountains. A stop of four days was made at Grant's Pass, type locality of Thomomys leucodon, which is situated on a level plateau on the north bank of the Rogue River in a mountainous region. The country is composed largely of granite or eruptive rocks, and is covered with a scattered forest of yellow pine, Pinus jeffreyi, sugar pine, Pinus lambertina, Douglas fir, Pseudotsuga taxifolia, and several species of white and live oaks. It is a Transition region allied more closely to the Sacramento Valley than to the Willamette.

\section{ORDER UNGULATA.}

\section{FAM. CERVID}

\section{Odocoileus columbianus.}

\section{ODOCOILEUS.}

Odocoileus columbianus. (Rich.), Faun. Bor. Amer., r829, p. 257. Elliot, Syn. N. Am. Mamm., I903, p. 4 I.

Two specimens Agness, Curry Co., Oregon.

The genus Odocolleus was proposed by Rafinesque (Atlantic Journal, 1832 , No. 3, p. Io9) on a fossil premolar of some kind of deer. In the same year he instituted the genus Panallodon (Month. Am. Journ. Geol. and Nat. Scien.) on a jawbone of some mammal which he thought was "akin to Mazama" (Am. Month. Mag., I8I 7, vol. I, p. 44) another of his genera comprising "the Brockets." Dr. Merriam (Proc. Biol. Soc., Wash., I 898, p. 99) assumed that this fossil tooth belonged to the "Virginian deer, or some closely related form" this, however, being incapable of proof-and advocated the adoption of Odocoileus for our white-tailed deer, and rejected Panallodon, quite correctly, on its insufficient diagnosis. It becomes a question worthy of serious consideration whether a genus founded upon some fossil remains of an otherwise entirely unknown animal of a past age should be unhesitatingly adopted for a group of existing species that may be, in the majority of its characters, widely different from the extinct form. Also whether it is not inadvisable to adopt any genus of Paleontology in any branch of Zoölogy. It would seem that the rule forbidding the adoption of a genus in a branch of Zoölogy if alıeady 
employed in any other, might with profit be also made applicable to paleontological genera, in which case Odocoileus, even if it could be proved to stand for an animal akin to the Virginian deer, would not be available in Mammalogy, and Dorcelaphus, Glog. Handb. Naturg., I 84 I, p. I 40 would be the proper generic term for our whitetailed deer. To those who prefer to adopt paleontological genera in Mammalogy, Anoglochis, Croiz. and Jobért. Oss. Foss. Cervidæ, I 828, antedating Odocoileus, as suggested by Lydekker, is -respectfully submitted. Under any circumstances, Odocoileus, as at present defined, is most unsatisfactory.

\section{ORDER RODENTIA.}

FAM. SCIURIDÆ.

Sub. Fam. Sciurina.

\section{SCIURUS.}

\section{Sciurus griseus.}

A. Hesperosciurus.

Sciurus griseus. Ord, Guth. Geog., I8I5, p. 292. Elliot, Syn. N. Ain. Mamm., igor, p. 55 .

Five specimens: 2 from Petaluma and I from Eureka, California, 2 from Agness, 'Curry Co., Oregon.

This species was abundant in many of the localities visited but only the above specimens were preserved.

\section{Sciurus douglasi.}

\section{B. TAMIASCIURUS.}

Sciurus douglasi. Bach., Proc. Zoöl. Soc., I 838, p. 99. Elliot, Syn. N. Am. Mamm., I90I, p. 65.

Thirteen examples: I, Crescent City, California; I, Marshfield; 2, Goldbeach; I, Chetco; 6, Gardiner; and 2, Beaverton, Oregon.

Crescent City is the southern limit of the range of this species. Not abunclant.

\section{Sciurus d. mollipilosus.}

Sciurus d. mollipilosus. Aud. and Bach., Proc. Acad. Nat. Scien., Phil., I842, p. Iо2. Elliot, Syn. N. Am. Mamm., I90I, p. 65.

Fourteen specimens: 5, Mendocino, 2, Requa, California ; 7, Goldbeach, Oregon.

Apparently abundant, called Pine Squirrel at Requa. 
S. douglasi and $S$. $d$. mollipilosus appear to intergrade from Crescent City, California and Goldbeach, Oregon, for specimens from these localities may be attributed to either and are typical of neither form. The tail fringe varies in color from yellowish white to buff in the various individuals, but never as white as in mollipilosus, nor as deep in hue as in douglasi. At Marshfield typical douglasi occurs, and the Crescent City specimen, 2 from Goldbeach and I from Chetco, I have called douglasi as the tail fringe was darker than in the others. The Mendocino specimens were taken in July, and the pelage is worn and consequently is grayer than the fall pelage represented by the others, and at that season, except for the tail, there is not much difference to be observed between the forms. Writing of $S$. $d$. mollipilosus, Mr. Heller says "it is said to extend northward to the Rogue River, and perhaps it does inland in the Transition zone, but along the coast in the Canadian zone the Klamath marks its northern limit."

TAMIAS.

\section{Tamias townsendi ochrogenys.}

T'amias townsendi ochrogenys. Merr., Proc. Biol. Soc., Wash., I897, p. 206. Elliot, Syn. N. Am. Mamm., I90I, p. 7 I.

Forty-four specimens: I I, Mendocino (topotypes); ro, Eureka; I 2, Requa; I, Crescent City, California; 9, Goldbeach; I, Agness, Oregon.

Dr. Merriam separated this form mainly on account of its buff cheeks and underparts, and the absence of the black stripe between eye and nose. The Mendocino examples are topotypes and answer to Dr. Merriam's description, except two, taken as werre the others, in July, which have the underparts grayish white with the barest suspicion of a buff tinge. Otherwise they are like the other specimens from the same locality. One example from Eureka (August), and two from Goldbeach (September and October), are like the July Mendocino specimen, but all the rest from Eureka, Requa, Crescent City, Goldbeach, and Agness (July, August, and September), are in what I con. sider the post-breeding pelage, being much brighter, the dorsal stripes much more distinct, and the rumps in the majority lighter and grayer. There is a certain amount of individual variation perceptible among the specimens, as is usually seen in all species of Tamias at different seasons of the year, such as the depth of coloring on the sides of the body, and of the buff on the underparts, and the sharpness and clearness of the dorsal stripes. 


\section{Tamias townsendi littoralis.}

Tamias townsendi littoralis. Elliot, Pub. Field Columb. Mus., I 903 , I I I, p. I 53.

Nineteen examples: ro, Marshfield; I, Scottsburg; 4, Florence; 4, Gardiner, Oregon.

This sub-species is conspicuous for its lack of gray dorsal stripes, and the presence of the ochraceous face and distinct anteorbital stripes and white underparts. The specimens were all taken in November and December and are therefore in winter pelage, but the coat is not at all worn. In the paper in which this race was described I gave the differences between it and hindsi, ochrogenys and toinsendi.

\section{Tamias townsendi hindsi.}

Tamias townsendi hindsi. Gray, Ann. and Mag. Nat. Hist., I842, p. 264. Elliot, Syn. N. Am. Mamm., rgor, p. 70.

Twenty-three specimens: 20, Nicasio (topotypes); 3, Point Reyes, California.

\section{CITELLUS.}

\section{Citellus v. douglasi.}

Citellus v. douglasi. (Richards), Faun. Bor. Amer., r829, r, p. I 72. Elliot, Syn. N. Am. Mamm., I 901, p. 89, under Spermophilus.

Nine examples: 2, Petaluma; 3, Eureka, California; and 4 from Goldbeach, Oregon.

Considerable variation is observable among these specimens, some having the lower back very much darker than the others, and while the black patch on the back is conspicuous on the majority, yet two individuals from Goldbeach have little or no black on the back and the lower back and rump are light yellowish brown mottled with white as is seen in most species of beecheyi. As a rule, the hoary tail will serve to distinguish douglasi from its relatives, but not always, for sometimes, as is the case of one of these Goldbeach specimens, the tail is more brown than hoary, and its owner might be placed with either race. At Goldbeach this spermophile is common according to Mr. Heller on "rocky open hillsides, and is said to hibernate as soon as the heavy rains commence in November." At Eureka it is "abundant about Scotia in grain-fields and pastures, and said to be common inland, not found close to Humboldt Bay.", 
Subfam. Pteromyine.

SCIUROPTERUS.

\section{Sciurus alpinus oregonensis.}

Sciurus alpinus oregonensis. Bach., Jour. Acad. Nat. Scien., Phil., I 839 , VIII, p. IоI.

One specimen: Goldbeach, Oregon.

\section{FAM. HAPLODONTIDÆ.}

\section{Haplodontia pacifica.}

HAPLODONTIA.

Haplodontia pacifica. Merr., Proc. Biol. Soc., Wash., I899, p. I 9. Elliot, Syn. N. Am. Mamm., I90I, p. II4.

Twenty-three specimens: I, Agness, Curry Co., 5,000 feet alt.; 8, Gardiner; and 14 Florence, Oregon.

Of this species at Gardiner, Mr. Heller writes that it was "common everywhere on ridges and side hills. Bunches of freshly cut ferns were seen about the entrances of the burrows. A few of the fronds were carried into the burrows, but the greater part remained in bunches at the entrance. The fronds were all cut near the rootstock and were placed with their cut ends toward the burrow, usually within a few inches of the opening. Burrows which were placed in salal, were surrounded by freshly cut twigs of the shrub." At Florence in addition to the ferns and salal gathered about the burrows "Oregon grape" was also frequently present. I cannot separate the example from Agness taken at a high elevation from the present species.

\section{Haplodontia phæa.}

Haplodontia phæa. Merr., Proc. Biol. Soc., Wash., r899, p. 20. Elliot, Syn. N. Am. Mamm., Igor, p. i I4.

Ten examples: 2, Nicasio; 2, Point Reyes (topotypes); 6, Eureka, California.

A few colonies of this species occur at Nicasio (which is apparently its eastern limit), at the head of two or three cañons in moist places on the hillside. At Point Reyes, the type locality, only a few burrows were seen, but the species was said to be much more common on the coast slope of the hills which in places, are stated to be covered with them. At Eureka this animal was "abundant in forests, on damp hillsides, and along streams. It is said to live only in places where it can burrow down to water. They seldom dig their burrows in culti- 
MAY, 1903.

A List of Mamals-Elliot.

$18_{5}$

vated fields, and if any are present it is only where the brush is still standing. The burrows are usually placed amid patches of ferns on the rootstocks of which they subsist."

\section{FAM.MURIDÆ.}

\section{PEROMYSCUS.}

\section{Peromyscus texensis gambeli.}

Peromyscus texensis gambeli. (Baird), N. Am. Mamm., I857,

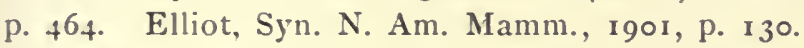

Twelve specimens: 8 , Nicasio: 4 , Petaluma.

\section{Peromyscus austerus.}

Peromyscus austerus. (Baird), Acad. Nat. Scien., Phil., I855, p. 336. Elliot, Syn. N. Am. Mamm., I 901, p. I32.

Fifty-nine examples: 16, Goldbeach; 2, Agness; 5, Grant's Pass; 3. Marshfield; 5. Scottsburg; 20, Gardiner; 6, Florence; 2, McCoy, Oregon.

There is considerable variation in the measurements among the specimens of this series, averaging considerably larger than those given in my Synopsis, which must be regarded as belonging to an undersized individual. The smallest are from Grant's Pass, the measurements of which range in total length, $154-179$; tail vertebræ, 60-89; hind foot, 21-22.5; ear, I6-18.5 all adults; and the largest are from Gardiner, I79-198; 86-101; 22-24; 18-20, with Goldbeach a close second with $175-200 ; 85-100 ; 21.5-22.5 ; 18.5-20$. The coloring also varies somewhat, some being lighter than others, but it is a dark colored species almost black in some specimens, making any light shade conspicuous.

\section{Peromyscus perimekurus.}

Peromyscus perimekurus. Elliot, Pub. Fieid Columb. Mus., I 903 , I I I, p. I 56, Zoölogy.

Seven specimens: 5, Goldbeach; I, Florence; I, Agness.

This form is distinguished from $P$. austerus by a larger size and very long tail, and lighter coloring.

\section{Peromyscus oreas rubidus.}

Peromyscus oreas rubidus. Osgood, Proc. Biol. Soc., Wash., I90I, p. I93. Elliot, Syn. N. Am. Mamm., I901, p. I34.

Forty-five specimens: 8 , Mendocino (topotypes); 2, Point Reyes: Io, Eureka; I8, Requa; 7, Crescent City; California. 


\section{Peromyscus dyselius.}

Peromyscus dyselius. Elliot, Pub. Field Columb. Mus., r 898, r, p. 207, Zoöl. Elliot, Syn. N. Am. Mamm., r9or, p. I38.

'Two examples from Grant's Pass, Oregon.

\section{RHITHRODONTOMYS.}

\section{Rhithrodontomys longicaudus.}

Rhithrodontomys longicaudus. Baird, Mamm. N. Am., I857, p. 451. Elliot, Syn. N. Am. Mamm., r9or, p. I51.

Eleven specimens: I, Nicasio; 8, Petaluma (topotypes); I, Mendocino; I, Eureka, California.

Eureka, I believe, is the most northerly locality in which this species has been obtained.

\section{Rhithrodontomys klamathensis?}

Rhithrodontomys klamathensis. Merr., N. Am. Faun., No. I6, I 899, p. 93. Elliot, Syn. N. Am. Mamm., I9o I, p. I52.

One specimen from Grant's Pass, Oregon.

General character: Smaller than $R$. klamathensis, tail and hind foot shorter, rostrum long.

Color: General color grayish buff; back of head and back heavily lined with black causing the dorsal region to be almost black; narrow lateral line ochraceous; under parts white, plumbeous of under fur showing through; feet and hands white; tail above dusky, beneath white, ears pale brown.

Measurements: Total length, I30; tail vertebræ, 63; hind foot, I8; ear, I5; skull, occipito-nasal length, 21; Hensel, I5; zygomatic width, I I ; interorbital constriction, 3 ; length of nasals, 8 ; palatal arch to alveoli of incisors, 8 ; length of mandible, angle to alveoli of incisors, 9 .

The only species that this form can be coinpared with is R. klamathensis, from central northern California and Klamath County, Oregon, from which it differs in its smaller size and much shorter tail, and in its darker coloration on upper parts. The specimen is a young adult, and this may possibly account for the smaller measurements. I refer it provisionally to $R$. klamathensis Merr.

\section{Subfam. Neotomin.}

\section{Neotoma fuscipes.}

\section{NEOTOMA.}

Neotoma fuscipes. Baird, Mamm. N. Am., I857, p. 495. Elliot, Syn. N. Am. Mamm., r9or, p. 158. 
MAY, I 903.

A List of Mamals-Elliot.

Thirty-four specimens: 9, Nicasio; 7, Petaluma (topotypes); 4, Point Reyes; 2, Mendocino; I, Requa, California; 9, Goldbeach; 2, Grant's Pass, Oregon.

\section{TEONOMA.}

\section{Teonoma cinerea occidentalis.}

Neotoma cinerea occidentalis: Baird, Proc. Acad. Nat. Scien., Phila., I 855, p. 335. Elliot, Syn. N. Am. Mamm., I 901, p. I64.

'Two specimens from Requa, California.

These two examples appear referable to this species, and Requa is apparently the southern limit of Teonoma on the coast. Requa is out of the range of occidentalis as heretofore given, but I am unable to place these specimens with any other species. They differ from $T . f$. apicalis in having no white tip to their tails and are lighter in color generally, but not at all like Teonoma cinerea.

\section{Teonoma fusca.}

Neotoma occidentalis fusca. 'True, Proc. U. S. Nat. Mus., Wash., 1894, p. 354. Elliot, Syn. N. Am. Mamm., 190I, p. I65.

Nine examples from Florence, Oregon.

The differences displayed by this form from $T$. c. occidentalis would seem to entitle it to a distinct specific rank. At Florence Mr. Heller says this species was "common about old houses, logs, and hollow trees in the forest, and in such places they build their nests of moss and sticks. None secured here with white-tipped tails ( $N$. f. apicalis) as at Gardiner."

\section{Teonoma fusca apicalis.}

Neotoma fusca apicalis. Elliot, Pub. Field Columb. Mus., ir I, 1903, p. г60, Zoölogy.

Seven specimens from Gardiner, Oregon.

The great differences exhibited between the scaly and bushytailed wood-rats both in their pelage, tail covering, and cranial characters would seem to make it necessary to separate them as distinct genera instead of leaving the bushy-tailed species in a subgeneric division. The bushy, squirrel-like tail, and the elongated rostrum, widely spreading zygomata at posterior roots, long, narrow sagittal area, with broadest part behind, and great interorbital constriction exhibited by the skulls of the members of Tеомом a would make them easily recognizable from the scaly-tailed species of Nвотома, even if there were no differences in the outside covering. I have therefore here raised 'Teonoma to full generic rank. Mr. Heller says this rat 
is "found usually about deserted buildings. Apparently they do not build nests, but live in the rock piles."

\section{Evotomys obscurus.}

\section{EVOTOMYS.}

Evotomys obscurus. Merr., Proc. Biol. Soc., Wash., I897, p. 72. Elliot, Syn. N. Am. Mamm., I 901, p. I 76.

One specimen from Grant's Pass, Oregon.

This is the only representative of this genus in the collection and must be rare on the coast.

\section{MICROTUS.}

\section{Microtus canicaudus.}

\section{A. Microtus.}

Microtus canicaudus. Miller, Proc. Biol. Soc., Wash., I897, p. 67. Elliot, Syn. N. Am. Mamm., I9or, p. 185.

Seven specimens: 6, McCoy (topotypes); I, Beaverton, Oregon.

\section{Microtus californicus.}

Microtus californicus. (Peale), Mamm. U. S. Expl. Exped., i 848 , p. 46. Elliot, Syn. N. Am. Mamm., I 90 I, p. I86.

Forty-two examples: 21, Nicasio (topotypes); 5, Point Reyes; I I, Petaluma, California; 5, Grant's Pass, Oregon.

This species in Nicasio, the type locality, is now confined to fenced fields, and roadsides. In other places the cattle, says Mr. Heller, "have stamped out their burrows and driven them away from all the pastures and hillsides." The northern limit of this vole is the Klamath River on the coast.

\section{Microtus c. constrictus.}

Microtus c. constrictus. Bailey, N. Am. Faun., I900, No. I7, 1). 36. Elliot, Syn. N. Am. Mamm., I901, p. I 86.

Twenty-five examples: 9, Mendocino; r6, Eureka, California.

The type of this species came from the coast of California near Cape Mendocino, at Capetown (Bailey l. c.). None of the specimens in this collection came from exactly this locality, but not far away on both the north and south as given above. I have referred them to the present species, but they are so close to $M$. angusticeps, that it is almost impossible to distinguish them from each other, and I have no topotypes of the present species to assist me. Eureka and Crescent City, the latter the type locality of $M$. angusticeps, are not a great distance apart, and Eureka is close to Cape Mendocino, the type locality of $M$. constrictus. These two forms exemplify the great 
MAY, 1903.

A List of Mammals-Elliot.

difficulty any one experiences when endeavoring to distinguish the closely allied races of this perplexing genus.

\section{Microtus townsendi.}

Microtus townsendi. (Bachm.), Jour. Acad. Nat. Scien., Phila., I 839, p. 6o. Elliot, Syn. N. Am. Mamm., I gor, p. Igo.

Twenty-nine specimens: 20, Eureka, California; 8, Marshfield; I, McCoy, Oregon.

Mr. Heller says this species was "common about tide-water, with habits very similar to those of the muskrat. They tunnel into the dykes and river banks, building runways and holes which have an entrance beneath the water like Fiber. Besides these tunnels about banks, they construct runways through the grass in meadows like other species of Microtus. Several were observed diving from their slides along the banks of streams. Some were caught in traps set beneath the water for Fiber. Grass is the only material I have seen this species collect and carry into their nests."

\section{Microtus angusticeps.}

Microtus angusticeps. Bailey, Proc. Biöl. Soc., Wash., I 898, p. 86. Elliot, Syn. N. Am. Mamm., I901, p. 192.

Forty specimens: ro, Requa; Iо, Crescent City (topotypes), California; 20, Goldbeach, Oregon.

This vole Mr. Heller says was abundant everywhere near Crescent City from siramps to grain-fields, replacing $M$. californicus, which extends no farther north on the coast than the Klamath River.

\section{Microtus oregoni.}

\section{B. Chilotus.}

Microtus oregoni. (Bachm.), Jour. Acad. Nat. Scien., Phila., I839, p. 6o. Elliot, Syn. N. Am. Mamm., I 90 I, p. 200.

Twenty-one examples: Io, Eureka; 2, Requa, California; 4, Goldbeach ; 5, Beaverton, Oregon.

Two color phases are exhibited in this series, a dark phase (one specimen from Goldbeach being almost black) and the usual reddish hue.

\section{Fiber occipitalis.}

FIBER.

Fiber occipitalis. Elliot, Pub. Field Columb. Mus., I I I, I903, p. 162, Zoölogy.

Four specimens from Florence, Oregon. 


\section{Fiber spatulatus.}

Fiber spatulatus. Osgood, N. Am. Faun., No. I 9, p. 36. Elliot, Syn. N. Am. Mamm., I90I, p. 214.

One specimen from Beaverton, Oregon.

I place this example as $F$. spatulatus with a doubt. It differs from $F$. occipitalis in being smaller in all its measurements, and of a different color, not so rufous, and in having broader shorter nasals, these measuring, in total length, 19.5; anterior breadth, II ; posterior breadth, 3 ; the type of $F$. occipitalis having the nasals $22,10,4$, respectively. Unfortunately the entire posterior half of the skull belonging to the specimen is wanting, and so no comparison can be made to ascertain if it possesses the peculiar arch in the occipital outline.

\section{FAM. GEOMYIDÆ.}

\section{THOMOMYS.}

\section{Thomomys bulbivorus.}

A. Megascapheus.

Thomomys bulbivorus. (Richards), Faun. Bor. Amer., I829, I, p. 206, pl. I 8 B. Elliot, Syn. N. Am. Mamm., I901, p. 222.

Twelve specimens: 7, Beaverton; 5, McCoy, Oregon.

The examples from Beaverton are darker generally than those from McCoy, probably on account of age; the slaty plumbeous predominating. Mr. G. S. Miller has called attention, in his paper on this species (Proc. Biol. Soc., Wash., I 893, p. I I3), to the conspicuous differences the $T$. bulbivorus exhibits in its skull from other species, notably $T$. botte with which he compared it. The central surface of the exoccipital next the condyle is occupied by a deep groove running obliquely to the axis of the skull, while in botte this is flat; the audital bullæ are flatter and less inflated. The pterygoids are very broad laterally, strongly concave internally, with the hamuli converging at the tips. The shape of the pterygoids with their converging hamuli seems to be an important character, sufficiently so with the others named and the great size of the species to separate it subgenerically from all others of the genus Thomomys. Its great size alone would serve to distinguish it at any time. I would therefore propose for this species *Megascapheus as a subgeneric term, distinguished by the characters already mentioned.

Mr. Heller found this species fairly common in the vicinity of Beaverton, but they $\mathrm{dwelt}$, as he writes, in such a low, wet"country

* $\mu \hat{\varepsilon}$ ras, great, and $\sigma \times a ̀ \varphi s u ́ s$, a digger. 
MAY, 1903.

A 'List of Mamals-Elliot.

that it was difficult to trap them during the rainy season. 'They' were especially common in the onion beds of vegetable gardens.

\section{Thomomys leucodon.}

B. Тномомуs.

Thomomys leucodon. Merr., Proc. Biol. Soc., Wash., I897, p. 2r 5. Elliot, Syn. N. Am. Mainm., I90I, p. 223.

Six specimens (topotypes), Grant's Pass, Rogue River Valley, Oregon.

\section{Thomomys bottæ.}

Thomomys bottæ. (Edy. and Gerv.), Mag. Zoöl., I836, p. 23, pl. xxi., fig. 4 (teeth). Elliot, Syn. N. Am. Mamm., I901, p. 223:

Twelve examples: I, Nacasio; 6, Petaluma; I, Mendocino; 4, Requa, California.

\section{Thomomys laticeps.}

Thomomys laticeps. Baird, Proc. Acad. Nat. Scien., Phila., I855, p. 335. Elliot, Syn. N. Am. Mamm., r gor, p. 224.

Thirty-one specimens: r6, Eureka (Table Bluff, Humboldt Bay, topotypes); 6, Requa; 9, Crescent City, California.

Mr. Heller states that this species was abundant on the hillsides about the Bay, but not found about Scotia, or in the redwood timber. Many of the specimens from Humboldt Bay and occasionally one from Crescent City have the lower incisors pure white as in $T$. leucodon which lessens the specific value of that character considerably.

\section{Thomomys helleri.}

Thomomys helleri. Elliot, Pub. Field Columb. Mus., II I, I903, p. I65, Zoölogy.

Eleven specimens from Goldbeach, Oreğon.

\section{FAM. ZAPODID E.}

\section{Zapus trinotatus.}

\section{ZAPUS.}

Zapus trinotatus. Rhoads, Proc. Acad. Nat. Scien., Phil., I894, p. 42I. Elliot, Syn. N. Am. Mamm., r9or, p. 26 I.

Twenty-five specimens: 6, Crescent City; 4, Requa; Ir, Eureka, California; 4, Goldbeach, Oregon.

In this series great differences are observable in size and coloration among the specimens, caused by age and change of pelage from the summer to autumn when the dull-hued flanks are assumed. This 
change evidently takes place irregularly among individuals, for certain ones taken at the same place on the same day exhibit in the one the ochraceous buff sides, in the other the dull yellow sides. Any one not conversant with this change of pelage might be misled into thinking there were two species.

\section{FAM. LEPORIDE.}

LEPUS.

A. Silvilagus.

\section{Lepus floridanus ubericolor.}

Lepus floridanus ubericolor. Miller, Proc. Acad. Nat. Scien., Phil., I 899, p. 383. Elliot, Syn. N. Am. Mamm., I901, p. 282.

Twenty specimens: 2, Requa, California; 5, Goldbeach; 8, Florence; 5, Beaverton (topotypes), Oregon.

\section{Lepus bachmani.}

\section{B. Microlagus.}

Lepus bachmani. Waterh., Proc. Zoöl. Soc., I838, p. Iо3. Elliot, Syn. N. Am. Mamm., I90I, p. 28 I.

Ten examples: 3, Nicasio; 2, Petaluma; I, Point Reyes; I, Mendocino; 3, Eureka, California.

- This species does not seem to go farther north, at least on the coast, than Eureka, as the specimens from Requa cannot be separated from $L$. $f$. ubericolor, and somewhere between these places would seem to be the respective northern and southern littoral boundaries of the two forms. How far in the interior either of the two extends its limits beyond these points, or if it does so at all, I am not at present able to state.

\section{ORDER CARNIVORA.}

\section{FAM. FELID E.}

FELIS.

\section{Felis rufa oculea.}

A. LyNChus.

Felis rufa oculea. (Bangs), Proc. N. E. Zoöl. Club, 1899, p. 23. Elliot, Syn. N. Am. Mamm., I901, p. 297.

One specimen from Nicasio (topotype), California. 


\section{FAM. CANIDE.}

UROCYON.

\section{Urocyon cinereo-argenteus californicus.}

Urocyon cinereo-argenteus californicus. Mearns, Proc. U. S. Nat. Mus., Wash., I897, p. 459. Elliot, Syn. N. Am. Mamm., I 901 , p. 308. Two specimens: I, Mendocino; I, Nicasio, California.

\section{FAM. PROCYONIDE.}

\section{Procyon lotor hernandezi.}

Procyon lotor hernandezi. Wagl., Isis, I83I, p. 5I4. Elliot, Syn. N. Am. Mamm., I9or, p. 317.

One specimen: Goldbeach Oregon.

\section{FAM. MUSTELIDÆ.}

\section{Subfam. MelinÆ.}

\section{Mephitis occidentalis.}

\section{MEPHITIS.}

Mephitis occidentalis. Baird, Mamm. N. Am., I857, p. 195. Elliot, Syn. N. Am. Mamm., I 901 , p. 324.

Seven examples: I, Point Reyes; 5, Requa, California; I, Marshfield, Oregon.

The specimens from Requa have the white stripes on the back very much narrower than is exhibited by those from other localities, the examples from Point Reyes and Marshfield being exactly alike in this respect. The skulls of the Requa specimens are also much larger in every way.

\section{Spilogale phenax.}

\section{SPILOGALE.}

Spilogale phenax. Merr., N. Am. Faun., No. 4, 1890, p. I3. Elliot, Syn. N. Am. Mamm., I9or, p. 331.

Six specimens from Petaluma, California.

\section{Spilogale p. latifrons.}

Spilogale p. latifrons. Merr., N. Am. Faun., No. 4, 1890, p. 15. Elliot, Syn. N. Am. Mamm., rgor, p. 331.

Fifteen specimens: 3, Goldbeach; 4, Marshfield; 5, Gardiner; 3, Beaverton, Oregon. 
These examples are of large size with buff stripes and spots. The last molar is smaller than that of $S$. phenax.

\section{PUTORIUS.}

\section{A. Lutreola.}

\section{Putorius vison energumenus.}

Putorius vison energumenus. Bangs, Proc. Bost. Soc. Nat. Hist., I896, p. 5, pl. I I, fig. 3. Elliot, Syn. N. Am. Mamm., I 90 I, p. 340.

Two specimens: Goldbeach, Oregon.

\section{Putorius streatori.}

B. Arctogale.

Putorius streatori. Merr., N. Am. Faun., No. I I, I 896, p. I 3 . Elliot, Syn. N. Am. Mamm., r 90 r, p. 345.

Four specimens: 2, Goldbeach; I, Gardiner; r, Beaverton, Oregon.

\section{Putorius xanthogenys mundus.}

Putorius xanthogenys mundus. Bangs, Proc. N. E. Zoöl. Club, I899, p. 56. Elliot, Syn. N. Am. Mamm., I901, p. 350.

Two specimens: I, Nicasio; I, Point Reyes (topotype), California.

\section{Putorius xanthogenys oregonensis.}

Putorius xanthogenys oregonensis. Merr., N. Am. Faun., No. I I, I 896, p. 25. Elliot, Syn. N. Am. Mamm., I 90 I, p. $35^{\circ}$.

Three examples from Goldbeach, Oregon.

\section{ORDER INSECTIVORA.}

\section{FAM. SORICIDÆ.}

\section{Sorex vagrans.} SOREX.

Sorex vagrans. Baird, Mamm. N. Am., I857, p. I5, pl. xxvi, fig. I675. Elliot, Syn. N. Am. Mamm., I gor, p. 370.

Twenty-seven specimens: I, Mendocino; 5, Eureka; I, Requa; I, Crescent City, California ; 7, Grant's Pass ; 2, Gardiner; 8, McCoy; 2, Beaverton, Oregon.

These examples were taken in the months of August, September, and January, and exhibit the different pelages assumed in summer and winter, those taken in August having the russet coat, those in September having both the russet and the blackish brown coat of winter, even in the same locality, and the January ones, of course, the very dark pelage. In the winter and summer coats individuals present a very different appearance. 


\section{Sorex montereyensis.}

Sorex montereyensis. Merr., N. Am. Faun., No. Io, IS95, p. 79.

Thirty-one specimens: I6, Nicasio; 5, Point Reyes; 3, Petaluma; 2, Mendocino; 4, Eureka; I, Requa, California.

\section{Sorex trowbridgii.}

Sorex trowbridgii. Baird, Mamm. N. Am., I857, p. I3. Elliot, Syn. N. Am. Mamm., I 90 I, p. 373.

Eighteen examples: 5, Goldbeach; I3, Marshfield, Oregon.

These specimens are not typical and exhibit a tendency toward $S$. montereyensis, but I refer them provisionally to $S$, trowbridgii.

\section{Sorex pacificus.}

Sorex pacificus. Baird, Bull. U. S. Geol. and Geog. Surv., I 877 , i i I, p. 650. Elliot, Syn. N. Am. Mamm., r9o , p. 375.

Forty-four specimens: 3, Mendocino; I6, Requa; I 3, Eureka; I, Crescent City, California; 5, Goldbeach; 2, Marshfield; 2, Gardi. ner, Oregon.

The specimens of this series are very uniform in coloration, a slight depth in hue being noticeable in the winter pelage.

\section{Atophyrax bendirii.}

\section{ATOPHYRAX.}

Atophyrax bendirii. Merr., N. Am. Faun., No. 1о, I895, p. 95. Elliot, Syn. N. Am. Mamm., I9ог, p. 38 I.

Sorex bendirii palmeri. Merr., N. Am. Faun., No. 1о, I895, p. 97, pl. xii, figs. I-3. Elliot, Syn. N. Am. Mamm., I9or, p. 38I.

Five specimens: I, Mendocino; I, Requa, California; 2, Goldbeach; I, Marshfield, Oregon.

I refer these examples to this species, although their measurements are much greater than those given by Dr. Merriam (1. c.) for his type and other specimens, indeed some even exceeding those given for A. b. palmeri. The following are Dr. Merriam's measurements for his species and subspecies, and also those for my examples. Dr. Merriam's are the first three:

\begin{tabular}{|c|c|c|c|c|}
\hline te & $\begin{array}{c}\text { Total } \\
\text { length. }\end{array}$ & $\begin{array}{c}\text { Tail } \\
\text { vertebræ. }\end{array}$ & $\begin{array}{l}\text { Hind } \\
\text { foot. }\end{array}$ & Locality. \\
\hline $\begin{array}{l}\text { A.bendirii. Type-.... } \\
\text { A. bendirii. Average of } 3 \mathrm{spec} \\
\text { A. b. palmeri. Type } \\
\text { A.bendirii } \\
\text { A. bendirii } \\
\text { A.bendirii } \\
\text { A. bendirii } \\
\text { A. bendirii }\end{array}$ & $\begin{array}{l}150 . \\
150.3 \\
165 . \\
159 . \\
176 . \\
160 . \\
172 . \\
164\end{array}$ & $\begin{array}{l}68 . \\
69.7 \\
73 \\
70 . \\
78 . \\
71 . \\
80 . \\
68 .\end{array}$ & $\begin{array}{l}20 . \\
19.7 \\
20 . \\
20 . \\
21.5 \\
21.5 \\
22 . \\
21 .\end{array}$ & $\begin{array}{l}\text { Klamath Basin, Ore. } \\
\text { Mendocino Co., Calif. } \\
\text { Astoria, Ore. } \\
\text { Mendocino, Calif. } \\
\text { Requa, Calif. } \\
\text { Goldbeach, Ore. } \\
\text { Goldbeach, Ore. } \\
\text { Marshfield, Ore. }\end{array}$ \\
\hline
\end{tabular}


From these measurements it would naturally be inferred that $A$. bendirii varies considerably in its dimensions like all other species of mammals, for even a California example is much larger than the type of $A$. b. palmeri, separated on account of its size, which character can hardly be considered to be sufficient to distinguish the two forms, and in the absence of any other will necessitate the reduction of A. b. palmeri to a synonym of $A$. bendirii.

\section{FAM. TALPIDA.}

Subfam. Myogaline.

NEÜROTRICHUS.

\section{Neürotrichus gibbsi major.}

Neürotrichus gibbsi major. Merr., N. Am. Faun., No. 16, 1899, 1. 88. Elliot, Syn. N. Am. Mamm., I901, p. 387 .

Seven specimens: 6, Eureka, California; I, Goldbeach, Oregon.

I refer these specimens to this species as they all possess a distinct anterior cusp on the cingulum of the large premolar, this being absent in examples of $N$. gibbsi. The extreme dimensions of the specimens are, total length, II $3^{-125}$; tail vertebræ, $38-42$; hind foot, I $5 \cdot 5 \cdot 16.5$.

Of this species Mr. Heller writes that its "habits are said to be similar to those of Sorex, that is, no runways are made as is the case with Scapanus, but they appear to live like shrews under logs, etc. Food not known, but perhaps different from Sorex, as they will not take bait, such as bacon, in the traps."

\section{Scapanus townsendi.}

\section{SCAPANUS.}

Scapanus townsendi. (Bachman), Jour. Acad. Nat. Scien., Phil., I839, viii, pl. I, p. 58. Elliot, Syn. N. Am. Maınm., I9or, p. 39 I.

Four specimens: 3, Crescent City, California; I, Goldbeach, Oregon.

These four examples are very large, much larger than the type, and measure in the extremes as follows: "Total length, 208-231; tail vertebræ, 42-46; hind foot, 26-28.

At Eureka Mr. Heller states this species was "fairly common throughout the redwood forests, and in moist bottom land. Several skins preserved by the farmers were examined, all of this species; one skin had large white anal and pectoral patches." At Crescent City this mole was "abundant in black bottom soil; rarely found in red soil." 


\section{Scapanus orarius.}

Scapanus orarius. 'True, Proc. U. S. Nat. Mus., 1897, p. 52. Elliot, Syn. N. Am. Mamm., r9or, p. 392.

Three specimens: I, Mendocino; 2, Crescent City, California.

The type of this species came from Shoalwater Bay, Washington, and the range is given by Dr. True as the "sea coast of Washington and Oregon from the Coquille River northward and along the shores of Puget Sound to Simiahmoo and to Chiloweyuck Depot and Sumas, British Columbia, and Fort Walla Walla, Washington." Now all these localities are far to the north of those from which the specimens obtained by Mr. Heller came, and Crescent City. California, has produced both species, yet $\mathrm{F}$ am unable to refer the three examples to any other than Dr. 'True's species. 'Their extreme measurements are: Total length, r68-1 74; tail vertebræ, 35-39; hind foot, 20.5-21; larger, it will be observed, than the dimensions given by Dr. True of his type, but in the same proportion to the specimens of $S$. townsendi from Crescent City, as those exceed the type of that species. It would seem that both forms are larger in the southern part of their range. I am not aware that $S$. orarius has been recorded before so far to the south.

\section{Scapanus californicus.}

Scapanus californicus. (Ayres), Proc. Calif. Acad. Scien., 1855, I, p. 54. Elliot, Syn. N. Am. Mamm., I901, p. 392.

Two specimens from Mendocino, California.

These examples are very large, far exceeding in their dimensions the recorded measurements. These are as follows: Total length, i 88 and 200 ; tail vertebræ, 37 and 42 ; hind foot, 24 and 25.

\section{ORDER CHIROPTERA.}

\section{Subfam. Plecotine.}

\section{CORYNORHINUS.}

\section{Corynorhinus townsendi.}

Corynorhinus townsendi. (Cooper), Ann. Ly.c. Nat.'Hist., N. I., iv, p. 73. Elliot, Syn. N. Am. Mamm., I901, p. 400.

Six specimens from Goldbeach, Oregon. 





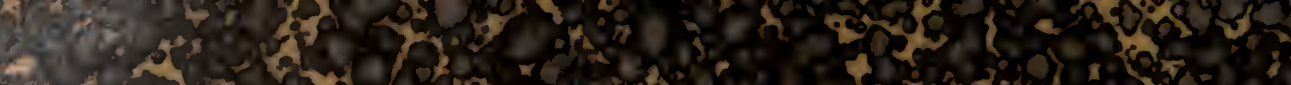

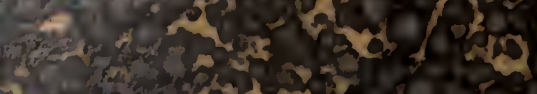

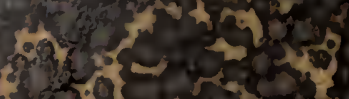
3 (a)

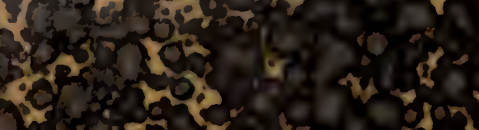

10 is

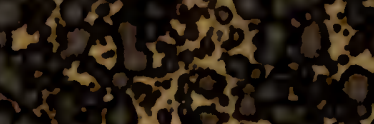

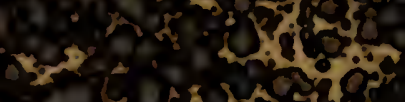

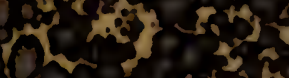
(1) )

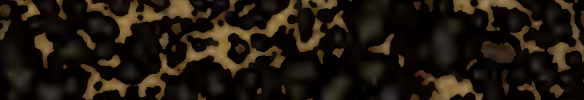

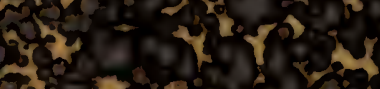

(1) on

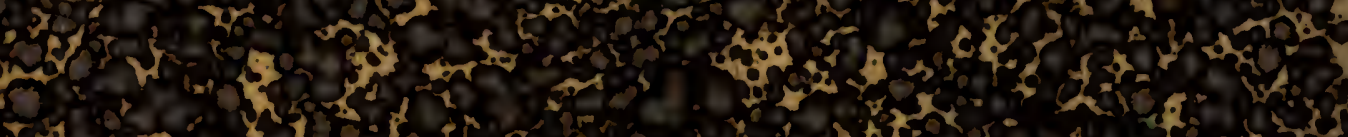
5.

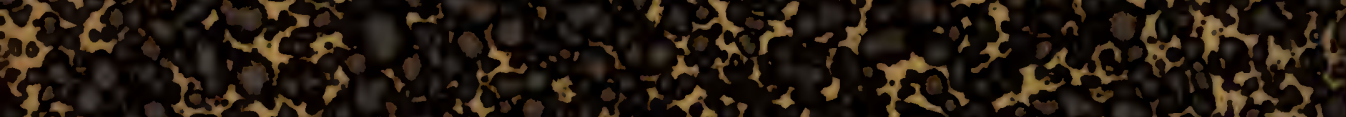

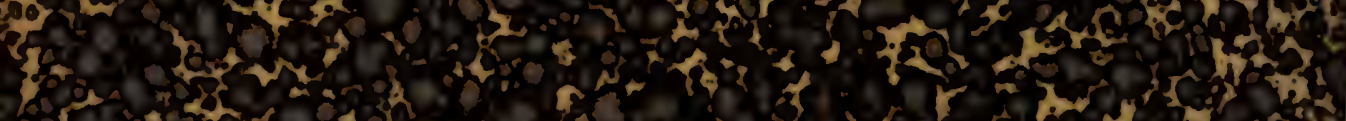
5. $2-20$

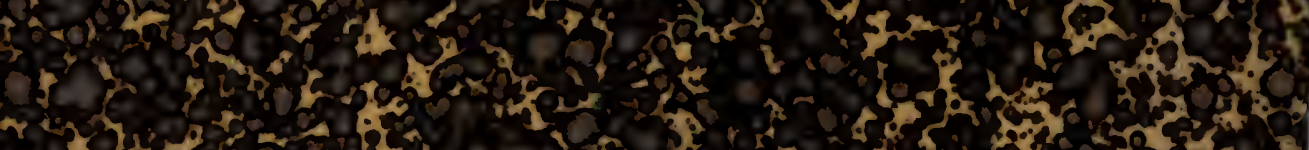

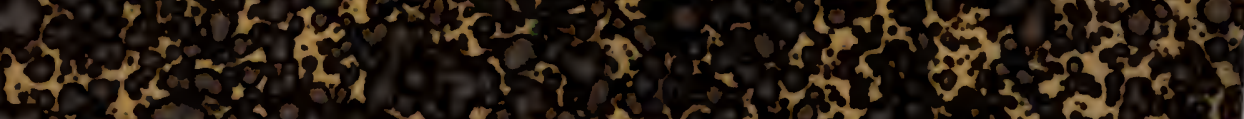
ars $x^{2} x^{2}$ ( $)$. 5.t. H

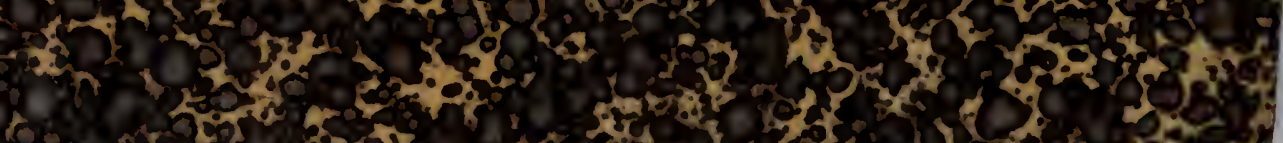

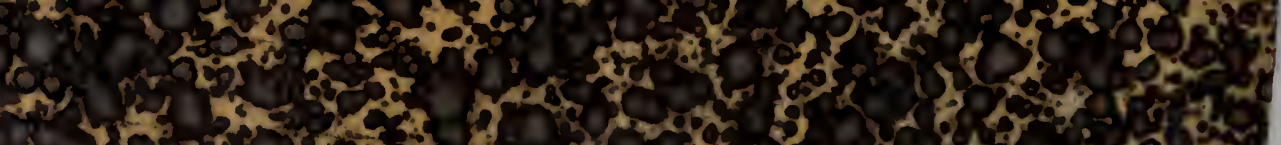

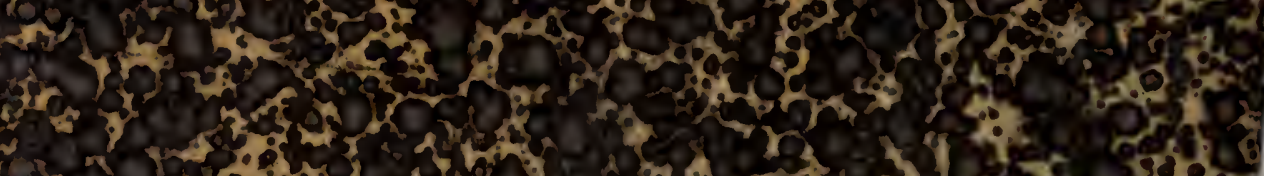

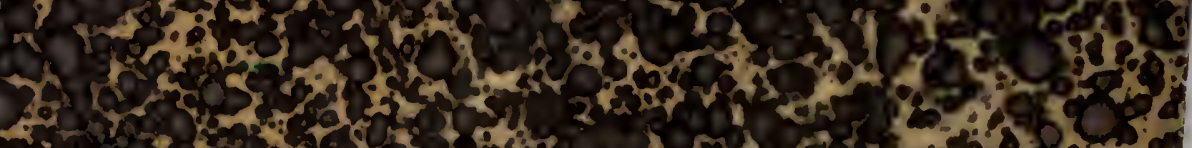

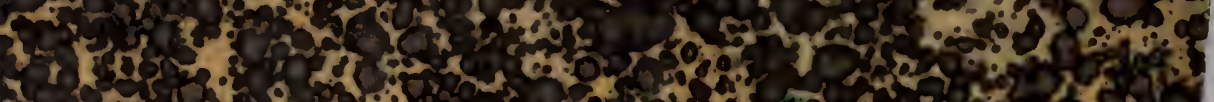

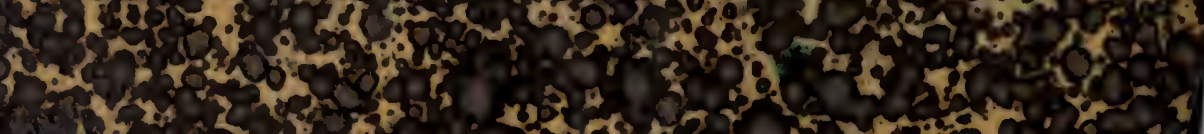

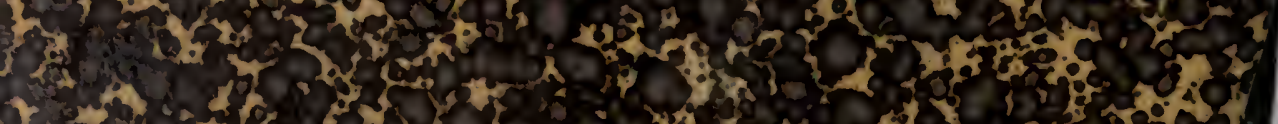

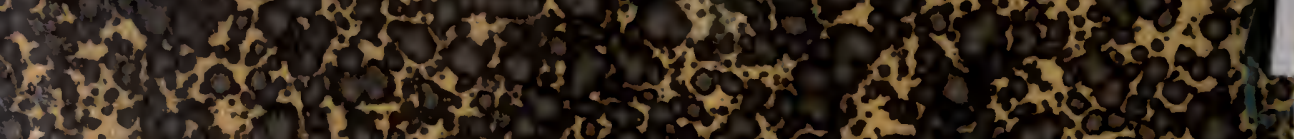

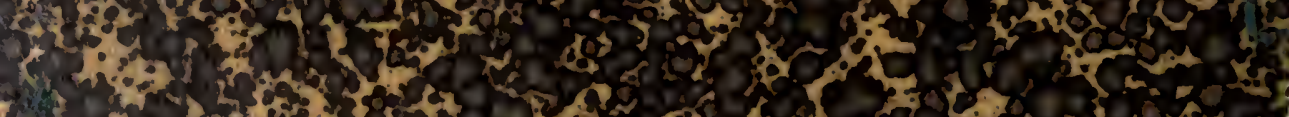

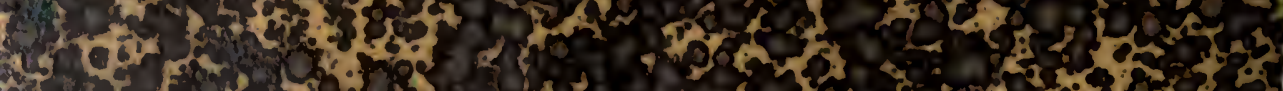

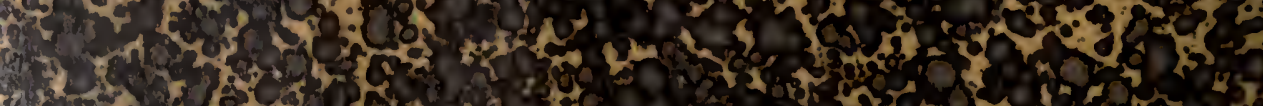

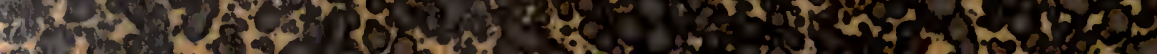




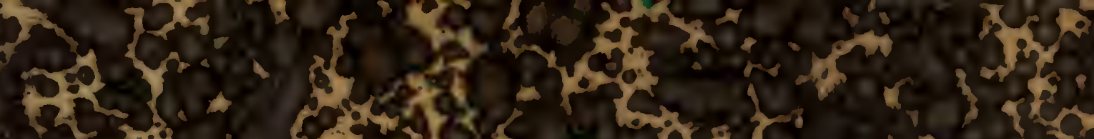

t.

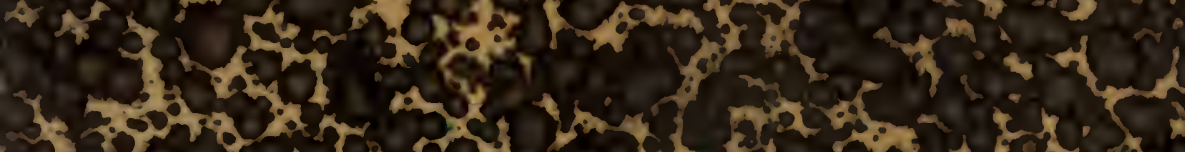

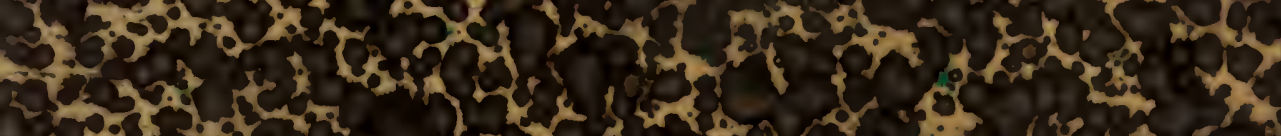

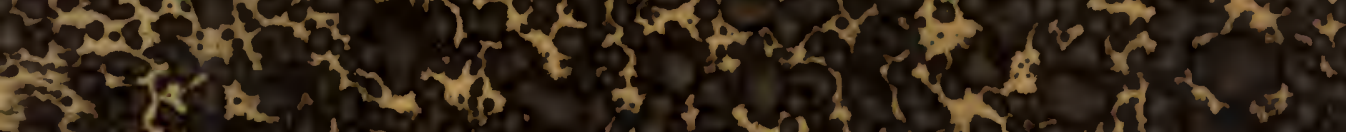

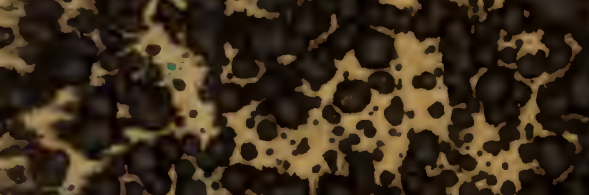
i.
(a) 15
sin:

(2) 1000

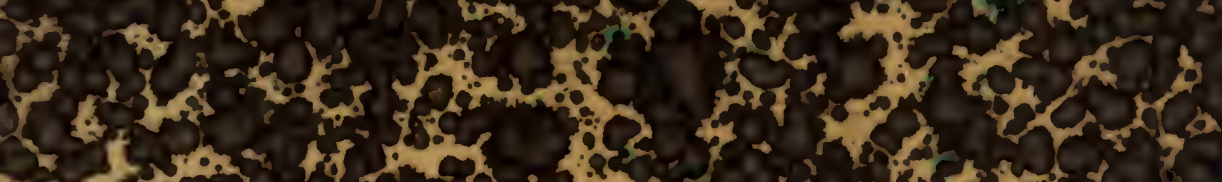

तit

ats

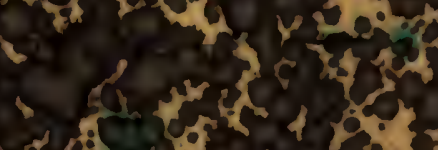

8.1

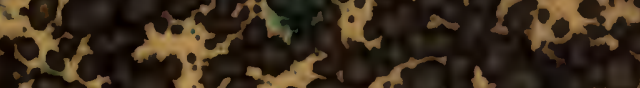

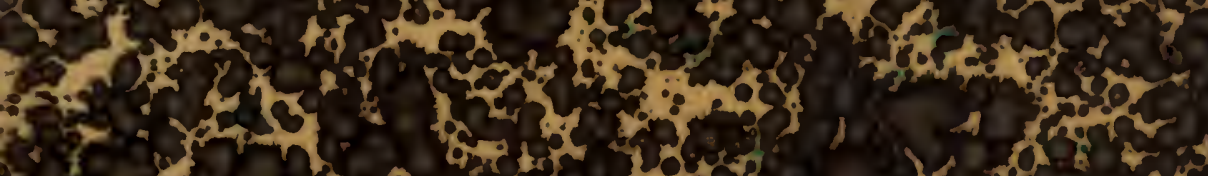

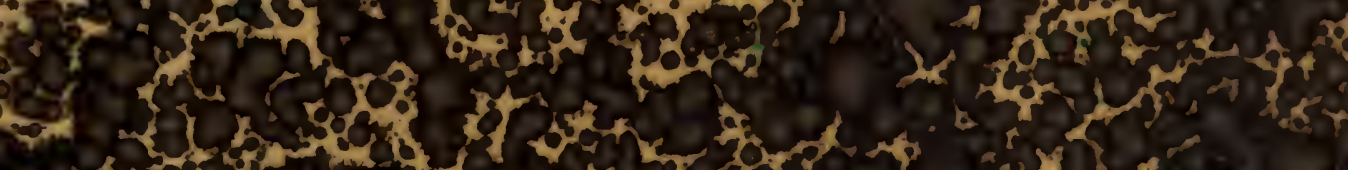

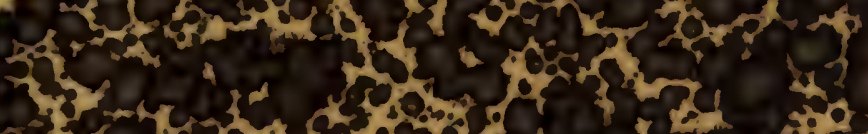

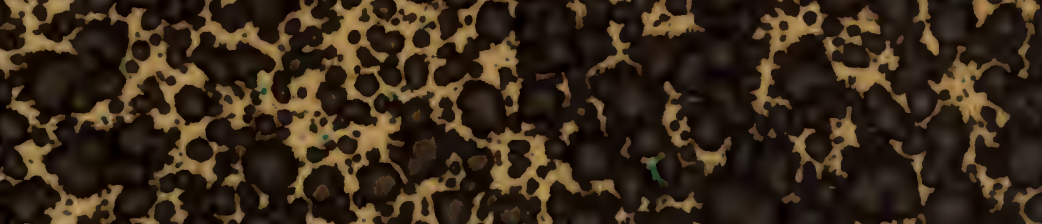

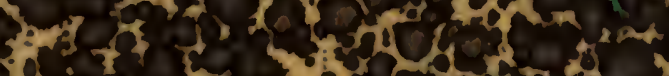

(t) 5 ond o

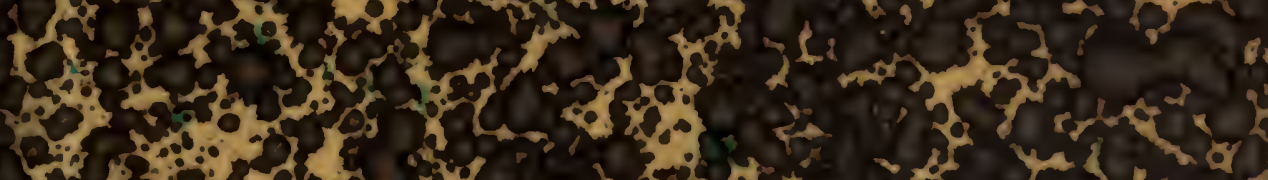
tev

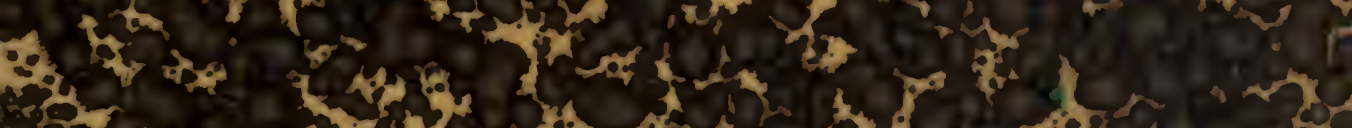

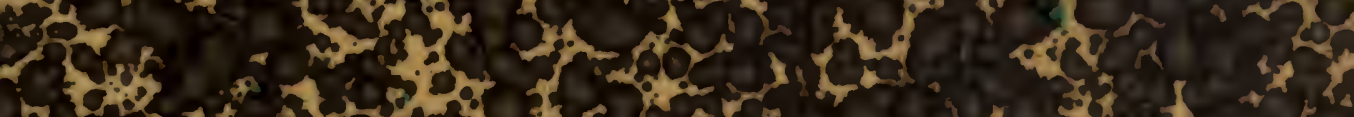

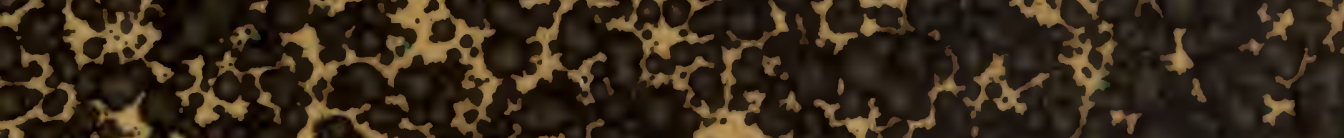

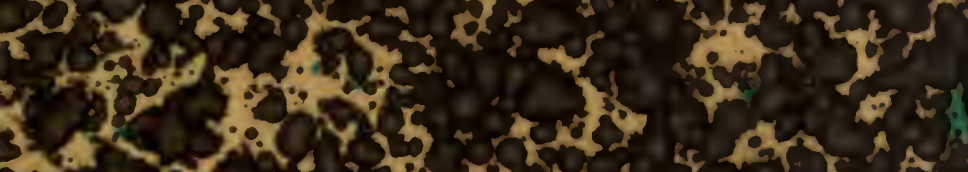

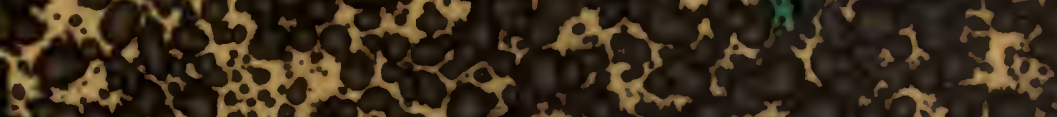

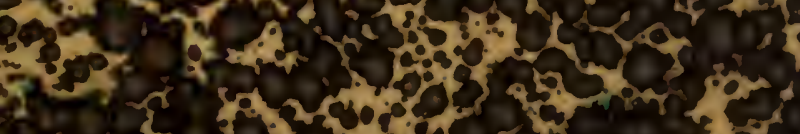
o 5 xo.

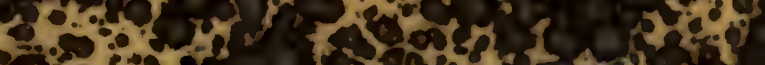

$\sum_{0}^{2} x^{2}+x^{2}$ 
